\begin{tabular}{|l|l|l|}
\hline \multicolumn{2}{|c|}{ PublisherInfo } \\
\hline \hline PublisherName & $:$ & BioMed Central \\
\hline \hline PublisherLocation & $:$ & London \\
\hline \hline PublisherImprintName & $:$ & BioMed Central \\
\hline \hline
\end{tabular}

\title{
Ultrasound for percutaneous tracheostomy
}

\begin{tabular}{|l|l|l||}
\hline \multicolumn{2}{|c||}{ ArticleInfo } \\
\hline \hline ArticleID & $:$ & 4073 \\
\hline \hline ArticleDOI & $:$ & $10.1186 /$ ccf-1999-1061 \\
\hline \hline ArticleCitationID & $:$ & 1061 \\
\hline \hline ArticleSequenceNumber & $:$ & 10 \\
\hline \hline ArticleCategory & $:$ & Paper Report \\
\hline \hline ArticleFirstPage & $:$ & 1 \\
\hline \hline ArticleLastPage & $:$ & 3 \\
\hline \hline & & RegistrationDate : 1999-7-20 \\
\hline ArticleHistory & $:$ & OnlineDate \\
\hline \hline ArticleCopyright & $:$ & Current Science Ltd1999-7-20 \\
\hline \hline ArticleGrants & $:$ & \\
\hline \hline ArticleContext & $:$ & 130541111 \\
\hline \hline
\end{tabular}




\section{Keywords}

Complications, percutaneous tracheostomy, ultrasound

\section{Comments}

Ultrasonography has a useful role for teaching and identification of difficult anatomy in many procedures previously performed blind on the ICU. This paper explores its role in percutaneous tracheostomy for reducing haemorrhagic complications and those late complications due to malposition of the tracheal stoma. Unfortunately these machines are expensive to buy for the ICU, although access to this equipment may be possible through the radiology department.

\section{Introduction}

Complications associated with percutaneous tracheostomy, including haemorrhage and misplacement of tracheal stoma, may in part be a consequence of difficulties in identifying landmarks. Ultrasound has the ability to accurately visualise large vessels and ascertain the level of tracheal puncture and thus potentially reduce these complications in those patients with a difficult anatomy.

\section{Aims}

A prospective observational study utilising ultrasound to clarify anatomy prior to percutaneous tracheostomy on the intensive care unit (ICU).

\section{Methods}

Prior to percutaneous tracheostomy, using the Ciaglia technique, 30 patients underwent ultrasonography of the pretracheal area by a single operator. Level and midline of the trachea were identified, along with thyroid and vasculature anatomy. 


\section{Results}

Anatomy was easily identified in all cases even in those considered to be obese or with short necks. Anterior jugular veins were identified in 15 patients of which eight were considered to be high risk from bleeding during tracheostomy. All underwent successful tracheostomy with one patient requiring elective ligation of this vein. Four patients had arteries in vulnerable positions; carotid arteries in two and brachiocephalic in the other two (one of whom was having conservative treatment for a thoracic dissecting aneurysm!)

\section{Discussion}

Ultrasonography of the neck is a simple, quick and safe method for identifying anatomy prior to percutaneous tracheostomy. It may reduce early bleeding complications and reduce some of the late complications brought about by malposition of the stoma.

\section{References}

1. Hatfield A, Bodenham A: Portable ultrasonic scanning of the anterior neck before percutaneous dilatational tracheostomy. Anaesthesia . 1999, 54: 660-663.

This PDF file was created after publication. 